\title{
Nepotizm Algısında Demografik Özelliklerin Rolü: Otel İşletmeleri İşgörenleri Üzerinde Bir Araştırma ${ }^{1}$
}

\author{
Doç. Dr. Elbeyi PELITT
}

Afyon Kocatepe Üniversitesi, Turizm Fakültesi, E-posta: elbeyipelit@aku.edu.tr Doç. Dr. Ahmet BAYTOK

Afyon Kocatepe Üniversitesi, Turizm Fakültesi, E-posta: ahmetbaytok@aku.edu.tr Doç. Dr. H. Hüseyin SOYBALI

Afyon Kocatepe Üniversitesi, Turizm Fakültesi, E-posta: hsoybali@aku.edu.tr Doç. Dr. İbrahim KILIÇ

Afyon Kocatepe Üniversitesi, Biyoistatistik Anabilimdalı, E-posta: kilicibrahim@aku.edu.tr

Öz

$\mathrm{Bu}$ araştırmanın amacı, örgütlerde önemli bir sorun grubunu oluşturan nepotizme (akraba, eş-dost kayırmacılığı) ilişkin, işgören algılarının bazı demografik özelliklerine göre değişip değişmediğini ortaya koymaktır. Bu kapsamda araştırma kapsamındaki otel işletmeleri işgörenlerinin nepotizm algılarının belirlenmesinde anket tekniğinden faydalanılmış ve nepotizm ölçeği araştırma kapsamındaki Afyonkarahisar'da faaliyet gösteren beş yıldızlı otel işletmeleri işgörenleri üzerinde uygulanmıştır. Anket tekniği ile elde edilen verilerin çözümlenmesinde betimsel istatistiklerin yanı sıra t-testi ve varyans analizlerinden faydalanılmıştır. $\mathrm{Bu}$ kapsamda araştırmaya katılan otel işletmeleri işgörenlerinin nepotizm algıları orta düzeye yakın gerçekleşmiş olup, işgörenlerin bazı demografik özellikleri ile nepotizm algılamaları arasında farklılıklar tespit edilmiştir. Söz konusu sonuçlar araştırmanın amacı doğrultusunda yorumlanarak konuya yönelik öneriler geliştirilmiştir.

Anahtar Kelimeler: Nepotizm, Otel işletmeleri işgörenleri, Afyonkarahisar.

\section{Önerilen Atıf:}

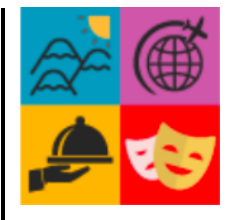

Türk Turizm Araştırmaları Dergisi

Cilt. 1, Sayı.2, 2017

ss. $45-63$.

DOI: $10.26677 /$ tutad.2017.8

Pelit, E. Baytok, A. Soybalı, H. H. ve Kılıç, İ. (2017). Nepotizm Algısında Demografik Özelliklerin Rolü: Otel İşletmeleri İşgörenleri Üzerinde Bir Araştırma, Türk Turizm Araştırmaları Dergisi, C:1, S:2, ss.45-63.

\footnotetext{
1 Bu çalışma, Afyon Kocatepe Üniversitesi Bilimsel Araştırma Projeleri Koordinasyon Birimi'nce desteklenen “Nepotizmin Yöneticiye Duyulan Güvene Etkisi: Afyonkarahisar'daki Beş Yıldızlı Otellerde Bir Uygulama" başlıklı proje çalışmasından üretilmiştir. (Proje No: 16.KARIYYR.25)
} 


\title{
The Role of Demographic Characteristics in the Nepotism Perception: An Application on the Hotel Business Employees
}

Associate Prof. Dr. Elbeyi PELİT

Afyon Kocatepe Üniversitesi, Turizm Fakültesi, e-mail_elbeyipelit@aku.edu.tr

Associate Prof. Dr. Ahmet BAYTOK

Afyon Kocatepe Üniversitesi, Turizm Fakültesi, e-mail_hmetbaytok@aku.edu.tr

Associate Prof. Dr. H. Hüseyin SOYBALI

Afyon Kocatepe Üniversitesi, Turizm Fakültesi, e-mail: hsoybali@aku.edu.tr

Associate Prof. Dr. İbrahim KILIÇ

Afyon Kocatepe Üniversitesi, Biyoistatistik Anabilimdalı, e-mail kilicibrahim@aku.edu.tr

\begin{abstract}
The aim of this research is to determine whether the perceptions of the employees change in terms of nepotism, (favoritism of relatives, kith and kin) which constitutes an important problem in organizations. In this context, in the determination of the nepotism perceptions of the employees in hotels in the scope of the research, the survey technique was utilized, and then the survey including the nepotism scale was applied to the hotel business employees in Afyonkarahisar. In the analysis of the data obtained by the questionnaire technique, t-test and variance analyzes were used in addition to descriptive statistics. In this context, the nepotism perceptions of hotel employees' participating in the survey were found to be close to the middle level, and significant differences were found out according to some demographic characteristics of the hotel employees and their nepotism perceptions. These mentioned results were interpreted in the direction of the research purpose and suggestions were developed about this subject issue.
\end{abstract}

Key Words: Nepotism, Hotel employees, Afyonkarahisar.

\section{Suggested Citation:}

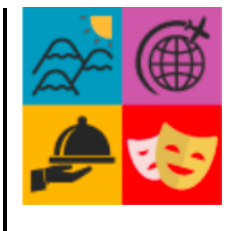

Journal of Turkish Tourism Research Vol. 1, Issue.2, 2017

pp. $45-63$.

Pelit, E. Baytok, A. Soybalı, H. H. and Kılıç, İ. (2017).The Role of Demographic Characteristics in the Nepotism Perception: An Application on the Hotel Business Employees, Journal of Turkish Tourism Research, Vol.1, Issue.2, pp.45-63. 


\section{Gíriş}

Nepotizm uygulamaları, özünde işe alım sürecinde ve terfide kan bağı ilişkileri dikkate alınarak seçim yapılmasıdır. Bu açıdan insan kaynakları yönetimi kapsamında değerlendirildiğinde hem işletme hem de çalışan için olumsuz etki oluşturma potansiyeli olan bir olgudur. Nitekim konuyla ilgili olarak çeşitli işletme türlerinde gerçekleştirilen çalışmalarda (Abdalla vd., 1994; 1998; Ciulla, 2005; Hutcheson, 2002; Ichniowski, 1988; Araslı vd., 2006; Özler vd., 2007; Asunakutlu ve Avc1, 2009; 2010; Büte ve Tekarslan, 2010; Keleş vd., 2011) nepotizmin, örgüt çalışanlarının çalışma veya örgüte yönelik geliştirdikleri tutum/davranışları üzerindeki olumsuz etkileri üzerinde durulmaktadır. Nepotizm ile ilgili literatür incelendiğinde olgunun aile ve hizmet işletmelerinde karşılaşılma olasıllğıının diğer işletme türlerine oranla daha fazla olduğu yönünde bir görüşün hakim olduğu görülmektedir (Araslı vd, 2006; Büte, 2011a). Bununla birlikte faaliyette bulunduğu alan ne olursa olsun, herhangi bir örgüt ortamındaki nepotizm olgusunun işgörenler tarafından fark edilmesi, işgören açısından örgüte, yöneticilerine ve sahiplerine yönelik olumsuz tutumları tetikleyecek etkenleri de beraberinde getirmektedir. Gerek konuyla ilgili gerçekleştirilen çalışma sonuçları gerekse uygulamaya bakıldığında, nepotizmin karşılaşılma olasılığı yüksek işletmeler arasında hizmet işletmeleri ön sıralarda gelmektedir. Turizmin emek yoğun karakterine bağlı olarak örgütsel faaliyetlerin sürdürülmesinde insan kaynağının yoğun katılımının zorunluluğunu gerektirmesi, işgörenleri en önemli üretim kaynağı haline getirmekte ve işgücü hizmet kalitesinin temel belirleyicisi olmaktadır. Bu durum turizm işletmelerinde işletme sahiplerinin ve yöneticilerinin insan kaynağının seçimini ve terfi uygulamalarını iyi değerlendirilmelerini gerektirmektedir. Çünkü işgören seçimi ve terfi uygulamaları işgörenlerin işletmeleri ve yönetimlerine karşı tutum geliştirmelerinde ve güvenlerinde önemli rol oynamaktadır. İşletmelerde işgörenlerin işletmeye yaptıkları katkı ve karşılığında aldıkları pay arasında eşitsizlik olduğu ve adil olmayan bir işletmede çalıştıkları düşüncesi yöneticilerine olan güvenlerini olumsuz yönde etkileyecektir (Arslaner vd., 2014). Bu bağlamda işgörenlerin şahit oldukları nepotizm uygulamaları işletme için uzun vadede iş tatmini, işten ayrılma isteği, ağızdan ağıza iletişim gibi vb. olumsuz sonuçlara yol açabilecektir (Araslı vd., 2006: 296). Bu kapsamda özellikle bu konu ile ilgili sorunların olup olmadığı noktasındaki mevcut durumun araştırılması ve farkındalık sağlamaya dönük nepotizmin otel işletmeleri için bu denli önem taşıması ve genellikle yöneticilerin nepotizm uygulamasına başvurarak kan bağı bulunan ve akraba ilişkilerine dayalı personel seçiminin, yine iş süreçlerinde akrabalık ilişkileri olan bu kişilerin yöneticiler tarafından kayırılması/kollanması, bir taraftan diğer işgörenlerin örgütlerine yönelik geliştirecekleri tutumları etkileyebilecek nitelikte olması ve işgörenlerin bazı bireysel ve demografik özelliklerinin de bu doğrultuda rol oynama ihtimali, diğer taraftan bu konuda otelcilik sektörü üzerinde pek fazla araştırmaya rastlanmaması bu araştırmanın çıkış noktasını oluşturmuş ve böyle bir araştırma yapılmasının gerekliliğini ortaya çıkarmışır. Bu doğrultuda bu araştırmanın amacı, örgütlerde önemli bir sorun grubunu oluşturan nepotizmin, yöneticiye duyulan güven üzerindeki etkisinin belirlenmesidir. Araştırmada, Afyonkarahisar ilindeki otel işletmelerinde çalışan işgörenlerin nepotizm algıları ve yöneticiye duydukları güven düzeyi belirlenerek, iki değişken arasındaki ilişkiler ortaya konmaya çalışılmıştır. Araştırmadan elde edilen bulgular doğrultusunda yöneticiler başta olmak üzere, çalışanlar, işletmeler ve turizm sektörü üzerine öneriler geliştirilmiştir.

\section{KURAMSAL ÇERÇEVE}

Nepotizm kavramı, kelime kökü olarak Latincede "yeğen" veya "torun" anlamına gelen "nepos" sözcüğünden gelmektedir (Cuilla, 2005; Kiechel, 1984; Abdalla vd., 1994; Büte ve 
Tekarslan, 2010). Bununla birlikte Bellow (2003), kelimenin İtalyanca "nipote"den geldiğini belirtmekte ve "nepotismo" kelimesinin on dördüncü ve on beşinci yüzyılda papaların yozlaşmış bir uygulama olarak akrabalarını ve gayrimeşru çocukları belli makamlara atamalarını tanımlamak için kullanıldığını belirtmektedir (Akt. Cuilla, 2005:155). Kavram özünde birilerine iltimas geçmek, himaye etmek ve kayırma şeklidir. Nepotizm mevkiini ailesinin yararına suiistimal eden kişiler için kullanılan bir kavramdır. Bu nedenle bir kayırmacılık türü olan nepotizmde kan bağı öne çıkmaktadır (Erdem vd., 2013:55). Genel olarak, "bir kimsenin beceri, kabiliyet, başarı ve eğitim düzeyi gibi faktörlerin dikkate alınmaksızın veya işin gerektirdiği niteliklere sahip olmayan kişilerin sadece akrabalık ilişkileri esas alınarak istihdam edilmesi veya terfi ettirilmesi" (Masters, 1983; Özler vd., 2007) olarak tanımlanan nepotizm, iş yerinde liyakat yerine, akraba veya kan bağı olan kişilere bir takım ayrıcalıklar vermekten kaynaklanan kayırmacılık uygulamalarını içermektedir (Ford ve Mc Laughlin, 1985; Araslı ve Tümer, 2008; Büte, 2011). Bununla birlikte günümüzde nepotizm akrabaları işe almak olarak değil, daha ziyade yeteneksiz, beceriksiz, ehil olmayan akrabaların işe alınmasını tanımlamak için kullanılmaktadır (Cuilla, 2005).

Nepotizme ilişkin çizilen ve geliştirilen kavramsal çerçeve ve uygulamadaki işleyiş sosyal kimlik kuramında bahsedilen kayırmacılık güdüsünün bir sonucu olarak ortaya çıkmakta olup, konunun örgütsel ortama taşınması ile birlikte, ilgili literatürde nepotizmin örgütlerin önemli sorunlarından birini oluşturduğu ve genellikle olumsuz bir durumu ifade ettiği üzerinde (Bayhan, 2002; Abdalla vd., 1994; 1998; Aközer, 2003; Asunakutlu ve Avc1, 2010) durulmaktadır. Bununla birlikte, nepotizmin özellikle sahiplik yapısı bakımından bir aileye veya aile grubuna ait olan örgütlerin başarısına katkı sağlayıcı unsurları da içerisinde barındırdığına yönelik görüşler de mevcuttur. Bellow (2003), bu durumu iyi nepotizm olarak tanımlamakta ve bazı büyük firmaların akrabaları çalışan olarak işe almayı tercih etmelerinin gerekçesinde akrabaları yönetmenin diğer çalışanları yönetmede kolaylık sağladığına vurgu yapmaktadır. Araştırmacının vurgu yaptığı bir diğer husus bu tür uygulamaların örgüt içindeki dayanışma ve beraberlik duygusunu oluşturmanın ve örgüte bağl1lığı sağlamanın bir yolu olduğudur (Cuilla, 2005). Literatürde bu yaklaşımın doğruluğunu destekleyen çalışmalar bulunmaktadır. Örneğin Türkiye'de konuyla ilgili yapılan bir araştırmada (Özler vd., 2007), nepotizmin çalışanlara yönelik birtakım avantajlar oluşturduğunu ve "insanların tanıdık bir isim veya simayla karşılaştıklarında kendilerini daha güvende ve rahat hissedecekleri" belirtilmektedir. Nepotizm örgütlere bazı avantajlar sağlamasına rağmen, günümüzde özellikle çağdaş yönetim anlayışının ulaştığı önemli bir nokta olan profesyonel yönetim yapısına ters düşen bir durumu da ortaya çıkarmaktadır. Nitekim aile içi yardımlaşmanın ve çıkar bilincinin; mesleki görev duygusu, kollektif yaşama yönelik sorumluluk gibi etik değerlerden üstün tutulduğu ve sadece yakın kişilere güven duyulan bir yönetim anlayışı, bireyleri gönüllü sivil beraberlik kurma becerisinden de mahrum bırakmaktadır (Bayhan, 2002). Nepotizmin içeriğini de oluşturan söz konusu bu uygulamalar kişisel, toplumsal ve nihayetinde örgütteki sosyal ilişkilerdeki sadakatin de belirleyicisi olarak ekonomik akılcılığı ortadan kaldıracak ve gerek işe alımlarda, gerekse örgütsel ortamdaki diğer faaliyetlerin yürütülmesi sürecinde kayırmacılık olarak kendini gösterecektir (Fukuyama, 1998). Diğer taraftan nepotizmin, özellikle geleneksel bağların ve ilişkilerin yaşandığı ve piyasa mekanizmasının yeterince gelişmemiş olduğu ülkelerin örgütlerinde ve özellikle hizmet sektöründe daha yaygın ortaya çıtığı göz önüne alındığında (Özsemerci vd., 2002; Araslı vd., 2006; Özler vd., 2007), Türkiye gibi güç mesafesi yüksek ve kollektivist kültürel boyutta yer alan bir toplumda (Hofstede, 1998; Sargut, 2010) faaliyette bulunan örgütlerde daha fazla mevcut olması kaçınılmaz olacaktır. Söz konusu bu durum, toplumların/örgütlerin kendi iç dinamikleri ile açıklanabilse de (Türkiye'deki aile, yakın akraba, eş dost ilişkilerinin her şeyden önce gelmesi, geleneksel ölçütlere dayanan sosyal 
dayanışma vb.) bu husus, gerek bireysel gerekse örgütsel düzeyde yaratıcılığı da kısıtlayan etkenleri de içerisinde barındırmaktadır (Bayhan, 2002).

Otel işletmelerinde nepotizm uygulamaları ile ilgili çalışmalar değerlendirildiğinde örneğin Araslı vd., (2006) insan kaynakları yönetiminde nepotizmin önemli bir konu olduğunu ve olumsuz etkiler ortaya çıkardıklarını bulmuşlardır. Araştırmacıların bulgularına göre işgören işe alma, seçim, değerlendirme, terfi ve disiplin işlemlerinde adaletsiz uygulamalar gerçekleştirilmektedir. İşletmelerde gerçekleşen adaletsiz uygulamalara işletme yöneticileri de baskı nedeniyle herhangi bir müdahale de bulunamamaktadırlar. Bu durum sadece işgörenleri değil işletmelerde çalışma eğiliminde olan başka yöneticileri de olumsuz etkilemektedir. Araştırma sonuçlarına göre nepotizme maruz kalan, diğer bir ifade ile adil olmayan rekabetçi çevrede çalışma işgörenleri mutsuz etmekte ve işlerini yaparken demoralize olmaları sonucunu doğurmaktadır. Bu durumun bir diğer yansımasının işletme içinde yatay ve dikey yeni grup yapılanmalarının oluşmasına zemin hazırlaması olduğuna dikkat çeken araştırmacılar örneğin belli terfileri almak isteyen veya posizyonunu güvence altına almak isteyen bazı işgörenlerin bunu gerçekleştirmek için performanslarını arttırmak yerine işletme içinde etkinliği olan aile üyeleriyle ilişkilerini geliştirerek bunu gerçekleştirmeye yönelebileceklerine vurgu yapmaktadırlar. Nepotizm ve güven ilişkisinde belirleyici unsurlardan birisi örgütsel adalet olgusudur. Bu konuda daha önce vurgulandığı gibi Keleş vd., (2011) yaptıkları çalışmada aile işletmelerindeki nepotizm uygulamaları ile güven arasında negatif bir ilişki olduğu, diğer bir ifade ile nepotizm uygulamalarının örgütsel güven, azalttığı bulunmuştur.

Arslaner vd., (2014:72) aile işletmesi olarak faaliyet gösteren konaklama işletmelerinde nepotizm ve örgütsel adalet üzerine yaptıkları çalışmada nepotizm ve örgütsel adalet arasında anlamlı bir ilişki bulamamışlardır. Araştırmacılara göre bunun nedeni; diğer sektörlere oranlar turizm sektöründe müşteri unsurunun ve buna bağlı olarak işgören unsurunun önemidir. Konaklama işletmelerinde müşteri memnuniyetinin belirleyicisi olan hizmet kalitesinin temel belirleyicisinin işgören performansı olması bu durumun oluşma sebebi olabilir. Bununla birlikte araştırmacılar aile işletmesi olarak faaliyet göstermeyen otel işletmelerinde örgütsel adalet ve nepotizm arasında negatif yönlü anlamlı bir ilişki bulmuşlardır. Benzer bir çalışma gerçekleştiren Araslı vd., (2016) nepotizmin iş tatminine etkisinde prosedürel adaletin aracılık rolünü araştırdıkları çalışmalarında nepotizm uygulamalarının prosedürel adalet algısını azaltarak iş tatmini üzerinde negatif etki oluşturduğunu bulmuşlardır. Araştırma sonuçlarına göre nepotizm uygulamaları ile otelde yeteneksiz kişilerin işe alınması, haksız terfilerin yapılması, bazı çalışanlara taraflı davranılması diğer otel çalışanlarının örgütsel adalet algısını olumsuz yönde etkilemektedir. Araştırma sonuçlarına göre ayrıca çalışanların prosedürel adalet algısının artması iş tatminlerini arttırırken, nepotizm uygulamalarının artması iş tatminini azaltmaktadır. Araştırmacılar bu doğrultuda otel işletmelerinde insan kaynakları yönetimi kapsamında özellikle işe alma, personel seçme aşamalarında tanıdık aile yakını gibi unsurlara değil, işin niteliğine uygun yeterlilikte çalışanları işe almaya özen gösterilmesi gerektiği konusunda önerilerde bulunmakta ve insan kaynakları yönetimi stratejilerinin bu doğrultuda oluşturulması konusuna vurgu yapmaktadırlar.

Erdem vd., (2013) otel işletmelerinde bir kayırmacılık türü olan kronizmin (eş-dost) işgörenler tarafından nasıl algılandığı ile ilgili çalışmalarında otel işletmelerinde insan kaynakları uygulamalarında eş-dost kayırmacılığı sık rastlanmadığını tespit etmişlerdir. Bununla birlikte işgörenlerin algılarına göre en önemli farklılık esnek çalışma saatleridir. İşgörenler çalıştıkları işletmelerde bazı işgörenlerin daha esnek çalışma saatlerinin bulunduğunu belirtmişlerdir. İlgili çalışmanın sonuçları Arslaner vd., (2014) çalışmalarının sonuçları ile benzerlikler göstermektedir. Otel işletmelerinde gerçekleştirilen ve nepotizm ile örgütsel adalet arasındaki ilişkiyi inceleyen bir diğer çalışmada (Seçilmiş ve Uysal, 2016) nepotizm ve örgütsel adalet 
arasında negatif düşük düzeyli bir korelasyon olduğu bulunmuştur. Araştırmada nepotizmin en fazla etkilediği örgütsel adalet boyutunun dağıtımsal adalet boyutu olduğu görülmüştür. Araştırmacılar yöneticilere yönelik önerilerinde otel işletmelerinde nepotizmin olumsuz etkilerinden korunmak için üst yönetimin nepotizm uygulamalarından kaçınmalarını ve işgörenler tarafından adil olarak algılanan açık bir insan kaynakları yönetimi sistemi geliştirmelerini belirtmektedirler. Bir diğer öneri ise uzman firmalardan profesyonel destek alma yoluyla atama ve terfi süreçlerinin belirlenmesi yönündedir. Bu sayede sağlanacak kurumsallaşma ve profesyonellik kişisel ve keyfi uygulamaların önlenmesini kolaylaştıracaktır.

Genel olarak değerlendirildiğinde kayırmacıllğı söz konusu olduğu bir ortamda yetenek ve bilgi birikiminin ikinci plana itilmesi söz konusudur. Bu herhangi bir ayrıcalıklı birey ile rekabet etmek zorunda olan işgörenin işlerinde yükselmesini güçleştirmekte ve özellikle işletmeye verilen fiziksel ve düşünsel emek ile bunun karşılında edinilen kazanımlar arasındaki eşitsizlik olması durumu işletmeye ve yöneticiye güveni azaltmakta ve ortaya çıkan söz konusu güven eksikliği iş doyumunu, motivasyonu, örgütsel bağl1llğı ve performansı olumsuz yönde etkilemektedir (Erdem vd., 2013:56). Bu doğrultuda hizmetler sektörü içerisinde faaliyette bulunan ve turizm sektörünün en önemli işletme türlerinden birini oluşturan otel işletmelerinde insan kaynakları uygulamaları kapsamında işgörenlerin işe alınması, terfileri ve atamalarında nepotizmin uygulanması, işletmelerde çalışan diğer işgörenlerin işletmelerine ve yöneticilerine yönelik algılamalarını etkileyecektir. Bu ilişkinin negatif yönlü bir ilişki olarak ortaya çıkması beklenebilir. Eğer otel işletmelerinde işgörenlerin nepotizm uygulamalarına ait algılamaları yüksek ise örgütlerine ve yöneticilerine yönelik geliştirecekleri tutumlar da olumsuz olacaktır. Söz konusu bu tutumlarda ise kişilerin demografik özelliklerinin de yeri yadsınamayacak derece öneme sahiptir. Bu çerçevede bu çalışmada çalışanların nepotizm algılarında bazı demografik özelliklerinin rolü konusu ele alınarak, konuya yönelik öneriler geliştirilmiştir.

\section{ARAŞTIRMANIN AMACI VE ÖNEMI}

$\mathrm{Bu}$ araştırmanın amacı, örgütlerde önemli bir sorun grubunu oluşturan nepotizme yönelik çalışanların alglarını belirleyerek söz konusu bu algılarda bazı demografik özelliklerin rolü olup olmadığının ortaya konulmasıdır. Bu noktadan hareketle bu araştırmada, konuyla ilgili kuramsal temeller çerçevesindeki bilgilere yer verilerek, araştırma araştırmanın amacı doğrultusunda Türkiye'nin önemli turizm destinasyonlarından biri olan Afyonkarahisar merkezde faaliyette bulunan beş yıldızlı otel işgörenleri üzerinde gerçekleştirilen bir anket çalışması bulgularına yer verilerek sonuçlar araştırmanın amacı doğrultusunda yorumlanarak, konuya yönelik ilgili taraflara önerilerde bulunulmuştur. Bu çerçevede araştırma problemi doğrultusunda elde edilecek bulgular araştırmanın konusu itibari ile oldukça önemli görülmekte olup, literatüre katkısının yanı sıra ilgili kurum-kuruluş ve yöneticilere önemli veri kaynağı teşkil edeceği değerlendirilmektedir.

\section{YÖNTEM}

Araştırmanın evreni, Afyonkarahisar'da beş yıldızlı otel işletmesi çalışanlarıdır. Bu çerçevede Afyonkarahisar'da faaliyet göstermekte olan 7 otel işletmesinden örneklem seçilmiş olup, örneklem seçiminde işletmelerdeki departman farklılıkları dikkate alınarak tabakalı örnekleme yöntemine göre seçim yapılmıştır. Bu doğrultuda, araştırmada örneklemini oluşturan birimlerin (işgörenlerin) seçilmesinde, Özdamar (2001) ve Sekaran (2003) tarafından nicel araştırmalar için önerilen; örnekleme hacmi hesaplama formülünden $\left(n=s^{2} \cdot Z^{2} \alpha / d^{2}\right)$ yararlanılmıştır. Buna göre, 
standart sapma (s) değeri 1, 0,05 anlamlılık düzeyine karşılık $Z \alpha=1,96$ ve örneklem hatasını ifade eden etki büyüklüğü (d) 0,1 alınmış olup, örneklem büyüklüğü 384 olarak hesaplanmıştır. $\mathrm{Bu}$ doğrultuda, eksik, hatalı ve geriye dönmeyecek anketlerin olabileceği dikkate alınarak 450 anket dağıtılmış ve 417'si değerlendirmeye alınmıştır. Araştırmada veri toplama yöntemi olarak anket tekniğinden faydalanılmıştır. İlgili anket üç bölümden oluşmaktadır. Birinci bölümde katılımcıların bazı bireysel özelliklerine (cinsiyet, yaş, medeni durum, departman, çalışma süresi) yer verilmiş olup, ikinci bölümde nepotizm ölçeği yer almaktadır. Araştırmada, 14 maddeden oluşan nepotizm ölçeği için Ford ve McLaughin (1985) tarafından konuyla ilgili gerçekleştirilen çalışmadan ve Abdalla vd., (1998) tarafından oluşturulan ölçeğin Türkiye'deki uygulamasını gerçekleştiren Asunakutlu ve Avcı (2010)'nın geçerlik ve güvenirlik çalışmalarını da yapmak suretiyle kullandıkları "nepotizm ölçeği" kullanılmıştır. Araştırmada kullanılan ölçek için beşli Likert tipi derecelendirme kullanılmıştır. Araştırmada anket tekniği ile elde edilen veriler istatistiki paket program ile analiz edilmiş olup, bireysel özellikler frekans yüzde dağılımlarıyla sunulmuştur. Bununla birlikte işgörenlerin nepotizm algılarını belirlemek için betimsel istatistiksel yöntemlerinden frekans, yüzde, aritmetik ortalama ve standart sapma değerleri hesaplanmıştır. Diğer taraftan işgörenlerin nepotizm algılarının bazı demografik/bireysel özelliklerine göre karşılaştııılmasında paremetrik test varsayımları (normal dağılım, varyansların homojenliği, olasılıklı örnekleme yöntemlerinin kullanılması, her bir grupta en az 10 bireyin olması vb.) gerçekleştiği için bağımsız örneklemler için t-testi (independent samples t-test) ve tek yönlü varyans analizi (One Way ANOVA) kullanılmıştır. Çalışmada kullanılan ölçeğin güvenirliğine ilişkin iç tutarlılık katsayıları için Cronbah's Alpha katsayıları hesaplanmıştır. Buna göre Cronbah's Alpha katsayıları; nepotizm ölçeği için $\alpha=0,842$ ve yöneticiye duyulan güven ölçeği için $\alpha=0,857$ olarak hesaplanmıştır.

\section{BULGULAR}

\section{Katılımcıların Demografik Özelliklerine İlişkin Bulgular}

Araştırmaya katılan 417 işgörenin bazı bireysel özelliklerine göre dağılımı Tablo 1'de verilmiştir. Tablo 1'de görüldüğü üzere katılımcıların \%59,2'sini erkek işgören grubu oluştururken, \%40,8'ini kadın işgören grubu oluşturmaktadır. Katılımcıların cinsiyet değişkeni açısından büyük bir bölümünü erkek işgörenlerin oluşturması, otel işletmelerinde çalışmanın kendine has özellikleri ile açılanabilir. Kadın ve erkeklerin sahip olduğu fiziksel özellikler birbirinden farklıdır ve genellikle kadınlar yoğun, ağır ve uzun çalışma koşulları karşısında, erkeklere oranla çok avantaj sahibi olmayabilirler. Ayrıca, ataerkil yapı, aile yapısı, toplumsal yapı gibi faktörlerle birlikte kadınların çalışma dışındaki sorumlulukları da (annelik, ev işleri gibi) bay işgören oranının neden daha yüksek olduğuna dair açıklayıcı nitelikler taşımaktadır.

Tablo 1 incelendiğinde, en fazla katılımı \%34,5 ile 27-30 yaş arasında olan katılımcı grubu oluştururken, en az katılım ise \%6,2 ile en genç yaş grubu olan 18-22 yaş arasındaki ve \%6,7 ile 35 yaş ve üzerindeki katılımcı grubu oluşturmaktadır. Diğer yaş grupları incelendiğinde, $\% 29,5$ oranında 23-26 yaş arasında olan ve \%23,0 oranında ise 31-34 yaş arasında olan katılımcılar olduğu görülmektedir. Genel olarak bir değerlendirme yapıldığında, katılımcıların \%70,2'sinin 30 yaş ve altında katılımcılar olduğu görülmektedir. Bu durumun en önemli sebebi, turizm sektörünün ve hatta otel işletmelerinin emek-yoğun bir yapıda olması, büyük bir ölçüde insan gücüne dayanması ve yoğun tempo gerektirmesiyle ilgilidir. Fiziksel olarak genç bireylerin bu tür işletmeler için daha uygun olacağı aşikârdır. Katılımcıların medeni durumları incelendiğinde, katılımcıların \%56,6'sının bekâr olduğu ve \%43,4'ünün ise evli olduğu görülmektedir. Otel işletmeleri günün 24 saati hizmet sunmaktadır ve buna bağlı olarak genellikle vardiya sistemi vardır. Otel işletmelerinin doluluk oranlarına, organizasyonlara ve 
bazı özel durumlara (sayım yapılması, toplantılar, hazırlıklar vb.) göre işgörenler fazladan mesai yapmak durumunda kalabilmektedir. Bu yönüyle, otel işletmeleri bazı durumlar açısından aile yaşantısı ile çok fazla uyumlu olmayabilmektedir. Dolayısıyla otel işletmelerinde yer alan çoğu bölüm için genç ve bekâr işgörenler öncelikli olarak tercih edilmektedir.

Tablo 1: Katılımcıların Bazı Demografik Özelliklerine Göre Dağılımı

\begin{tabular}{|c|c|c|c|}
\hline & Değişken & Sayı (f) & Yüzde (\%) \\
\hline \multirow{2}{*}{ Cinsiyet } & Kadın & 170 & 40,8 \\
\hline & Erkek & 247 & 59,2 \\
\hline \multirow{5}{*}{ Yaş } & $18-22$ yaş & 26 & 6,2 \\
\hline & $23-26$ yaş & 123 & 29,5 \\
\hline & $27-30$ yaş & 144 & 34,5 \\
\hline & 31-34 yaş & 96 & 23,0 \\
\hline & 35 ve üzeri & 28 & 6,7 \\
\hline \multirow{2}{*}{ Medeni Hal } & Evli & 181 & 43,4 \\
\hline & Bekâr & 236 & 56,6 \\
\hline \multirow{4}{*}{ Departman } & Önbüro & 66 & 15,8 \\
\hline & Yiyecek-içecek & 192 & 46,0 \\
\hline & Kat Hizmetleri & 125 & 30,0 \\
\hline & Diğer (İK, SP, SPA, Hİ vb.) & 34 & 8,2 \\
\hline \multirow{5}{*}{$\begin{array}{c}\text { İşletmede } \\
\text { Çalışma Süreleri }\end{array}$} & $0-2$ yll & 60 & 14,4 \\
\hline & $3-5$ yil & 137 & 32,9 \\
\hline & $6-8 \mathrm{yil}$ & 120 & 28,8 \\
\hline & 9-11 yil & 55 & 13,2 \\
\hline & 12 ve üzeri & 45 & 10,8 \\
\hline
\end{tabular}

Genel olarak, otel işletmelerinde en fazla işgörene sahip olan bölümler F\&B (yiyecek ve içecek bölümü "-mutfak, bar ve restoranı kapsamaktadır-) bölümü ile kat hizmetleri bölümüdür. Bu araştırmada da doğal olarak en fazla katılım söz konusu iki bölümden gerçekleşmiştir. Katılımcıların \%46,0'sı yiyecek-içecek bölümünde, \%30,0'u ise kat hizmetlerinde çalışmaktadır. Tablo 1'de de görüleceği üzere $\% 15,8$ oranındaki katılımcıların önbüro da ve \%8,2 oranındaki katılımcıların ise insan kaynakları, SPA ve güzellik merkezleri, satış-pazarlama, halkla ilişkiler, güvenlik gibi bölümleri kapsayan diğer bölümlerde çalıştığı görülmektedir. Katılımcıların otel işletmelerindeki çalışma sürelerine ilişkin dağglımlarına göre, en fazla katılımı \%32,9 ile 3-5 yıl arası çalışanlar oluştururken, en az katılımı ise \%10,8 ile en fazla deneyime sahip olan 12 yıl ve üzerinde çalışan işgören grubu oluşturmaktadır. Diğer katılımcıların çalışma süreleri sırasıyla incelendiğinde, \%28,8 ile 6-8 yıl arası çalışanlar, \%14,4 ile 0-2 yıl arası çalışanlar ve \%13,2 ile 9-11 yıl arası çalışanlar olduğu görülmektedir. Genel bir değerlendirme yapıldığında, araştırma dâhilindeki otellerde çalışan işgörenlerin yarısından fazlası $(\% 52,8)$ en az 5 yıllık bir deneyime sahiptir.

\section{Katılımcıların Nepotizm Algılarına Yönelik Bulgular}

Araştırma kapsamında incelenen otel işletmeleri işgörenlerinin nepotizm algılarını belirlemek amacıyla kullanılan nepotizm ölçeğindeki her bir ifadeye ilişkin katılımcıların verdikleri yanıtların; yüzde dağılımları, aritmetik ortalama ve standart sapma değerleri ile genel aritmetik ortalama ve standart sapma değerleri detaylı olarak Tablo 2'de yer almaktadır. Bu kapsamda 
ölçeğin birinci ifadesi olan "bu işletmede çalışanların terfi etmesinde bilgi, beceri ve kabiliyetler ikinci planda kalmaktadır" ifadesine katılımcıların \%29,5'i hiç katılmadığını, \%13,9'u az düzeyde katıldığını, \%23,7'si orta düzeyde katıldığını, \%13,7'si çok katıldığını ve \%19,2'si ise tamamen katıldığını belirtmiştir. Söz konusu ifadeye verilen yanıtların aritmetik ortalaması $\bar{x}=2,79$ olarak, orta düzey olan "3" puanın altında hesaplanmıştır. Diğer bir ifadeyle katılımclların büyük bir bölümü, terfi etme konusunda liyakat sisteminin çok fazla işlemediği yönünde görüş bildirmiştir. Örgüt içinde yöneticilerin tanıdık kayırmasıyla ilgili ikinci ifade olan "bu işletmede ne kadar başarılı olursam olayım, işletme yöneticilerinin tanıdıklarının önüne geçemem" ifadesine verilen yanıtların aritmetik ortalaması $\bar{x}=2,89$ olarak hesaplanmıştır. İlgili ifade için katılımcıların \%22,8'i "hiç katılmıyorum", \%20,6'sı "az katılıyorum", \%21,1'i "orta düzeyde katılıyorum", \%15,8'i “çok katılıyorum" ve \%19,7'si ise "tamamen katılıyorum" yanıtını işaretlemiştir. Dolayısıyla, katılımcıların yarısından fazlası $(\% 56,6)$, orta derece ve üzerinde katılım göstererek ne kadar başarılı olursa olsunlar, yöneticilerinin tanıdıklarından daha fazla yükselemeyeceği algısından kaynaklanıyor olabilmektedir. Nepotizm ölçeğinin $\bar{x}=2,73$ aritmetik ortalamaya sahip üçüncü ifadesi olan "bu işletmede çalışanların terfi ettirilmesinde akrabalık ve yakınlık ilişkileri öncelikle dikkate alınır" ifadesine katılımcıların \%26,4'ü "hiç katılmıyorum", \%18,9'u "az katıllyorum", \%24,7'si "orta düzeyde katılıyorum", $\% 15,1$ 'i "çok katılıyorum" ve \%14,9'u "tamamen katılıyorum" seçeneklerini işaretleyerek, bazı otellerde adaletli olmayan terfi olanaklarının mevcut olduğunu belirtmiştir.

Dördüncü ifade olan "bu işletmede, işletme yöneticilerinin tanıdıklarının terfi etmesinin daha kolay olduğunu düşünüyorum" ifadesine katılımcıların \%20,1'i hiç katılmadığını, \%23,3'ü az düzeyde katıldığını, \%24,0'ü orta düzeyde katıldığını, \%18,0'i çok katıldığını ve \%14,6'sı ise tamamen katıldığını belirtmiştir. Aritmetik ortalaması $\bar{x}=2,84$ olan bu ifadeye verilen yanıtların bir önceki ifadenin yanıtlarıla benzerlik göstermekte olup, katılımcıların büyük bir bölümü terfi olanaklarında yakınlık ilişkilerinin önemli bir rol oynadığı görüşündedir. Aritmetik ortalaması $\bar{x}=2,82$ ve ölçeğin beşinci ifadesi olan "bu işletmede çalışanların terfi ettirilmesinde, işin gerektirdiği nitelikler dışındaki faktörler ön planda tutulmaktadır" ifadesine verilen yanıtlar incelendiğinde ise, katılımcıların sadece \%23,0'ü hiç katılmadığını belirtmiştir. Diğer yandan \%14,4'ü çalıştığı işletmede terfi ettirilme konusunda işin gerektirdiği nitelikler dışındaki faktörlerin tamamen ön planda tutulduğunu ifade etmiştir. Aynı şekilde azımsanamayacak bir oranda $(\% 17,5)$ katılımcı söz konusu ifadeye çok katıldığını belirtmektedir. Katılımcıların \%18,7'si söz konusu ifadeye az düzeyde, \%26,4'ü ise orta düzeyde katılım sağlamıştır.

Tablo 2'deki ölçeğin altıncı ifadesi olan "bu işletmenin yönetim kadrosunda tanıdığı olan çalışanlar diğer kişilerden itibar görmektedir" ifadesine verilen yanıtlar incelendiğinde, katılımcıların \%19,7'sinin "hiç katılmıyorum", \%20,1'inin "az katılıyorum", \%26,4'ünün "orta düzeyde katılıyorum", \%20,9'unun "çok katılıyorum" ve \%12,9'unun "tamamen katılıyorum" seçeneklerini işaretlemiş olduğu görülmektedir. $\bar{x}=2,87$ aritmetik ortalamaya sahip olan bu ifadeye verilen yanıtlar doğrultusunda, katılımcıların neredeyse yarısına yakını $(\% 33,8)$ bu ifadeye 4 (çok katılıyorum) ve 5 (tamamen katılıyorum) puan vererek, yönetici yakınlarının daha fazla itibar gördüğü yönünde görüş bildirmiştir. Alt ve orta kademe yöneticilerin adam kayırmasıyla ilgili olan "bu işletmedeki alt ve orta kademe yöneticiler, tanıdığı olan çalışanlara daha farklı davranmaktadır" ifadesinin aritmetik ortalaması $\bar{x}=2,88^{\prime}$ dir. Bu ifadeye verilen yanıtlara göre katılımcıların \%20,1'i hiç katılmadığını belirterek yöneticilerin herkese eşit ve adil davrandığını, \%19,4'ü az düzeyde katıldığını belirterek zaman zaman bu tür olayların olabileceğini işaret etmiştir. Diğer yanıtlar incelendiğinde, \%27,1 oranında katılımcının orta düzeyde, \%18,7 oranında katılımcının çok düzeyde ve \%14,6 oranında katılımcının tamamen katılım sağladığı görülmektedir. Diğer bir ifadeyle, araştırma kapsamında incelenen 417 
işgörenin \%60,4'ü çalıştıkları işletmedeki alt ve orta kademe yöneticilerin çalışanlar arasında adam kayırarak eşit ve adil davranmadığı yönünde görüş bildirmiştir. Nepotizm ölçeğinin sekizinci ifadesi olan "bu işletmede yöneticilerin tanıdıklarını işten çıkarmanın veya onlara ceza vermenin oldukça zor olduğunu düşünüyorum" ifadesine verilen yantların aritmetik ortalaması $\bar{x}=2,85$ olarak hesaplanmıştır. Bu ifadeye katılımcıların \%21,1'i "hiç katılmıyorum", \%22,1'i "az katılıyorum", \%23,0'ü "orta düzeyde katılıyorum", \%18,0'i "çok katıllyorum" ve $\% 15,8$ 'i ise "tamamen katılıyorum" yanıtını vermiştir. Bu sonuçlardan, katılımcıların büyük bir çoğunluğunun orta düzey olan 3 ve üzerinde puan vererek, yöneticilerin tanıdığı işgörenleri işten çıkarma veya cezalandırma huşunda adil ve eşit davranmadığı görüş bildirdiği söylenebilir.

Tablo 2: İşgörenlerin Nepotizm Algısına İlişkin Betimsel İstatistikler

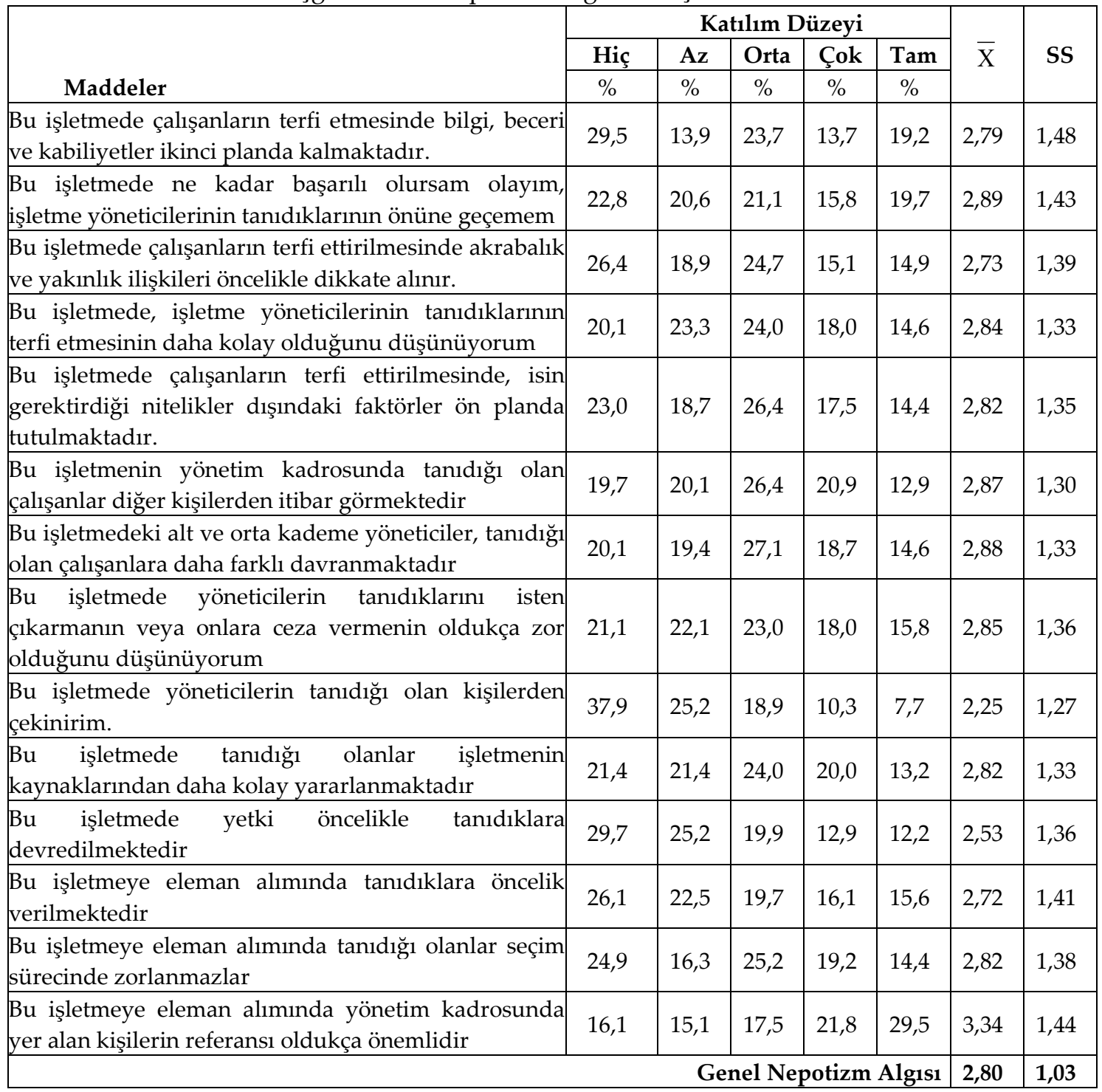

Katılımcların en az düzeyde katılım sağladığ 1 ve aritmetik ortalaması $\bar{x}=2,25$ olarak hesaplanmış olan ifade "bu işletmede yöneticilerin tanıdığı olan kişilerden çekinirim" ifadesidir. İşgörenlerin neredeyse yarısına tekabül eden $\% 37,9^{\prime} u$ bu ifadeye hiç katılmadığını belirterek, yöneticilerin tanıdığı olan diğer işgörenlerden hiç çekinmediğini ifade etmiştir. \%25,2 oranında 
katılımcı bu ifadeye az katıldığını, \%18,9'u orta düzeye katıldığını, \%10,3'ü çok katıldığını ve $\% 7,7^{\prime}$ si ise tamamen katıldığ yönünde görüş bildirmiştir. Söz konusu ifadeye 4 ve 5 puan veren $\% 18,0$ oranında katılımcının, yöneticilerin tanıdıklarından çekinmesinin sebebi, bu işgörenlerin yapılan hataları ve/veya konuşulanları yöneticiye iletebilecekleri kaygısından olabilir.

İşletmenin kaynaklarını kullanmayla ilgili ölçeğin onuncu ifadesi olan "bu işletmede tanıdığı olanlar işletmenin kaynaklarından daha kolay yararlanmaktadır" ifadesinin aritmetik ortalaması orta düzeye yakın $(\overline{\mathrm{x}}=2,82)$ bir değerde hesaplanmıştır. Bu ifadede katılımcıların \%21,4'ü "hiç katılmıyorum", \%21,4'ü "az katılıyorum", \%24,0'ü "orta düzeyde katılıyorum", $\% 20,0$ 'si "çok katılıyorum" ve \%13,2'si ise "tamamen katılıyorum" seçeneklerini işaretlemiştir. Dolayısıyla, katılımcların yine büyük bir bölümünü oluşturan $\% 57,2$ oranındaki katılımcı kitlesi 3 ve üzerinde puan vererek, işletme olanaklarından tanıdığı olan işgörenlerin daha kolay bir şekilde yararlanabileceği yönünde görüş bildirmiştir. Nepotizm ölçeğinin on birinci ifadesi olan "bu işletmede yetki öncelikle tanıdıklara devredilmektedir" ifadesinin aritmetik ortalaması $\bar{x}=2,53$ olarak hesaplanmıştır. Katılımcıların \%29,7'si bu ifadeye hiç katılmadığını, \%25,2'si az düzeyde katıldığını, \%19,9'u orta düzeyde katıldığını, \%12,9'u çok katıldığını ve \%12,2'si ise tamamen katıldığını belirtmiştir. Örgütlerdeki yetki devriyle ilgili olan bu ifadeye verilen yanıtlardan, yetki devrinin öncelikle tanıdıklara yapıldığıyla ilgili katılımcıların büyük bir çoğunluğu $(\% 54,9)$ olumsuz fikir beyan etmiştir. Ölçeğin takip eden on ikinci ifadesi ve $\bar{x}=2,72$ aritmetik ortalamaya sahip olan "bu işletmeye eleman alımında tanıdıklara öncelik verilmektedir" ifadesi Türkiye'de halk ağzında çokça kullanılan "dayının olması, tanıdığının olması" gibi ifadelerle benzerlik göstermektedir. Söz konusu ifadeye işgörenlerin \%26,1'i çalıştığı işletmenin elaman alımında tanıdıklarına hiç öncelik vermediğini ifade etmiştir. Benzer bir şekilde katılımcıların \%22,5'i bu ifadeye az katıldığını, \%19,7'si orta düzeyde katıldığını belirtirken, \%16,1'i çok katıldığını ve \%15,6'sı ise tamamen katıldığını ifade ederek çalıştıkları işletmenin eleman alımlarında tanıdıklara öncelik verildiğini belirtmiştir.

Araştırma kapsamında incelenen otel çalışanlarının on üçüncü ifade olan "bu işletmeye eleman alımında tanıdığı olanlar seçim sürecinde zorlanmazlar" ifadesine verdikleri yanıtların aritmetik ortalaması $\bar{x}=2,82$ olarak hesaplanmıştır. Söz konusu ifadeye verilen yanıtlara göre, katılımcıların \%24,9'u hiç katılmadığını, \%16,3'ü az katıldığını, \%25,2'si orta düzeyde katıldığını, \%19,2'si çok katıldığını ve \%14,4'ü ise tamamen katıldığını ifade etmiştir. Bu sonuçlara göre, katılımcıların büyük bir çoğunluğu $(\% 41,2) 1$ ve 2 puan vererek personel seçiminde tanıdıkların da zorlanabileceği yönünde görüş bildirirken, diğer katılımcılar 3 ve üzerinde puan vererek zorlanmayacakları yönünde görüş bildirmiştir. Nepotizm ölçeğinin sonuncu ve $\bar{x}=3,34$ ile en yüksek aritmetik ortalamasına sahip olan ifade "bu işletmeye eleman alımında yönetim kadrosunda yer alan kişilerin referansı oldukça önemlidir" ifadesidir. Katılımclların \%29,5'i "tamamen katılıyorum", \%21,8'i "çok katılıyorum", \%17,5'i "orta düzeyde katılıyorum" seçeneklerini işaretleyip söz konusu nispeten daha olumlu görüş bildirirken; \%15,1'i "az katılıyorum" ve \%16,1'i ise "hiç katılmıyorum" seçeneklerini işaretleyerek yönetim kadrosunda yer alan yöneticilerin referansının çok önemli olmadı̆̆ını belirtmiştir.

Araştırma kapsamında incelenen otel işletmeleri işgörenlerinin genel olarak nepotizm algıları orta düzeye yakın bir değerde, $\bar{x}=2,80$ olduğu tespit edilmiştir. Her ne kadar düşük gibi görünse de nepotizm algısı örgütler için önemli bir sorun niteliği taşıdığından, bu değerin önemle üzerinde durulması gereken bir değer olduğu söylenebilir. 


\section{Katılımcılarım Nepotizm Algılarının Demografik Özelliklerine Göre Karşılaştırılmasına İlişkin Bulgular}

Afyonkarahisar'da faaliyet gösteren 5 yıldızlı otel işletmelerinde çalışan işgörenlerin nepotizm algıları ve işgörenlerin sahip olduğu bazı bireysel/demografik özellikler (cinsiyet, yaş, medeni durum, çalışılan departman ve çalışma süresi) açısından karşılaştırılması ve aralarında anlamlı farklılıklar olup olmadı̆̆ını ortaya koymak amacıyla $t$ testi ve tek yönlü varyans (One Way Anova) analizlerine başvurulmuştur.

Bu doğrultuda, otel işletmelerinde çalışan işgörenlerin nepotizm algılarının cinsiyet değişkeni açısından farklılık gösterip göstermediğini belirlemek amacıyla yapılan t-testinin sonuçları Tablo 3'de gösterilmiştir.

Tablo 3: Katılımcıların Nepotizm Algılarının Cinsiyete Göre Karşılaştırılması

\begin{tabular}{|l|l|r|r|r|c|}
\hline \multirow{2}{*}{ Ölçek } & \multicolumn{1}{|c|}{ Cins } & $\bar{X}$ & SS & $\mathbf{t}$ & $\mathbf{p}$ \\
\hline \multirow{2}{*}{ Nepotizm } & Kadıt & 2,81 & 1,04 & \multirow{2}{*}{0,342} & 0,240 \\
\cline { 2 - 6 } & Erkek & 2,78 & 1,02 & \\
\hline
\end{tabular}

Tablo 3'deki değerler incelendiğinde, otel işletmelerinde çalışan işgörenlerin nepotizm algıları $(\mathrm{t}=0,342 ; \mathrm{p}=0,240)$ cinsiyet değişkeni açısından 0,05 anlamlılık düzeyinde anlamlı bir farklılık göstermemektedir. İşgörenlerin nepotizm algıları cinsiyetlerine göre değerlendirildiğinde, hem kadın katılımciların $(\bar{x}=2,81)$ hem de erkek katılımciların $(\bar{x}=2,78)$ ortalamaları birbirine yakın değerlerde olduğu, ancak kadın katılımcıların nispeten daha fazla olduğu gözlenmiştir.

Tablo 4: Katılımcıların Nepotizm Algılarının Yaşa Göre Karşılaştırılması

\begin{tabular}{|c|c|c|c|c|c|}
\hline Ölçek & Yaş & $\bar{X}$ & SS & $F$ & p \\
\hline \multirow{5}{*}{ Nepotizm } & 18-22 yaş & 2,31 & 0,97 & \multirow{5}{*}{1,977} & \multirow{5}{*}{0,097} \\
\hline & $23-26$ yaş & 2,85 & 1,09 & & \\
\hline & $27-30$ yaş & 2,81 & 1,02 & & \\
\hline & $31-34$ yaş & 2,88 & 1,00 & & \\
\hline & 35 ve üzeri & 2,59 & 0,85 & & \\
\hline
\end{tabular}

İşörenlerin nepotizm algılarının yaş değişkenine göre karşılaştırılması ve söz konusu iki değişken arasında anlamlı farklılıkların olup olmadığını test etmek amacıyla tek yönlü varyans (One Way Anova) analizinden yararlanılmıştır. Bu doğrultuda, iki değişken arasında yaş açısından anlamlı bir farklılık olup olmadığını test etmek amacıyla yapılan tek yönlü varyans analizinin sonuçları Tablo 4'te ayrıntılı olarak sunulmuştur. Tablo 4 'te yer alan değerlere göre, işgörenlerin nepotizm algıları $(\mathrm{F}=1,977 ; \mathrm{p}=0,097)$ yaşları açısından 0,05 anlamlılık düzeyinde anlamlı bir farklılık göstermemektedir. Bununla birlikte, nepotizm algıları açısından 31-34 yaş arasında olan işgörenlerin ortalamaları en yüksek değere $(\bar{x}=2,88)$ sahipken, bunu sırasıyla 23-26 yaş arasında olanlar ( $\bar{x}=2,85), 27-30$ yaş arasında olanlar $(\bar{x}=2,18)$, 35 yaş ve üzerinde olanlar $(\bar{x}=2,59)$ ve $18-22$ yaş arasında olanlar $(\bar{x}=2,31)$ takip etmektedir.

Katılımcların nepotizm algılarının medeni durumları açısından karşılaştııılması ve iki değişken arasında anlamlı bir farklılık olup olmadığını belirlemek amacıyla t-testinden yararlanılmış ve gerçekleştirilen t-testi sonuçları Tablo 5'de sunulmuştur. Tablo 5'deki test sonuçlarına göre, 
katılımcıların nepotizm algılarının $(t=2,152 ; p=0,032)$ medeni durum değişkeni açısından, grup ortalamaları arasında 0,05 anlamlılık düzeyinde istatistiki açıdan anlamlı bir farklılık olduğu tespit edilmiştir. Medeni durum değişkenine göre, evli olan işgörenlerin nepotizm algıları $(\bar{x}=3,00)$, bekâr olan işgörenlere $(\bar{x}=2,63)$ oranla daha yüksek düzeyde bulunmuştur.

Tablo 5: Katılımcıların Nepotizm Algılarının Medeni Duruma Göre Karşılaştırılması

\begin{tabular}{|l|l|c|c|c|c|}
\hline \multirow{2}{*}{ Ölçek } & $\begin{array}{l}\text { Medeni } \\
\text { Durum }\end{array}$ & $\bar{X}$ & SS & $\mathbf{t}$ & $\mathbf{p}$ \\
\hline \multirow{2}{*}{ Nepotizm } & Evli & 3,00 & 1,05 & 2,152 & $0,032^{*}$ \\
\cline { 2 - 6 } & Bekâr & 2,63 & 0,99 & 2,15 \\
\hline
\end{tabular}

$" p<0,05 ; " * *<<0,01$

İşgörenlerin nepotizm algılarının çalıştıkları departmana göre karşılaştırılması ve iki değişken arasında anlamlı bir farklılık olup olmadığını test etmek amacıyla tek yönlü varyans (One Way Anova) analizi uygulanmıştır. Yapılan tek yönlü varyans analizinin sonuçlarına Tablo 6'da ayrıntılı olarak yer verilmiştir.

Tablo 6: Katılımcıların Nepotizm Algılarının Departmana Göre Karşılaştırılması

\begin{tabular}{|l|l|r|r|c|c|}
\hline Ölçek & \multicolumn{1}{|c|}{ Departman } & $\overline{\mathrm{X}}$ & \multicolumn{1}{|c|}{ SS } & F & p \\
\hline \multirow{4}{*}{ Nepotizm } & Önbüro & 2,75 & 1,08 & & \\
\cline { 2 - 4 } & Yiyecek-içecek & 2,85 & 1,02 & \multirow{3}{*}{2,550} & \multirow{2}{*}{0,055} \\
\cline { 2 - 4 } & Kat Hizmetleri & 2,85 & 1,00 & & \\
\cline { 2 - 4 } & Diğer (İK, SP, Hİ vb.) & 2,34 & 1,01 & & \\
\hline
\end{tabular}

Tablo 6'daki varyans analizi sonuçları incelendiğinde, katılımcıların nepotizm algıları ( $\mathrm{F}=2,550$; $\mathrm{p}=0,055)$, çalıştıkları departman açısından 0,05 anlamlılık düzeyinde anlamlı bir farklılık göstermediği anlaşılmaktadır. Bununla birlikte, işgörenlerin çalıştıkları departman açısından, yiyecek-içecek bölümü $(\bar{x}=2,85)$ ve kat hizmetleri bölümünde $(\bar{x}=2,85)$ çalışan işgörenlerin nepotizm algıları, önbüro bölümünde $(\bar{x}=2,75)$ ve insan kaynakları, SPA, halkla ilişkiler gibi diğer bölümlerde $(\bar{x}=2,34)$ çalışan işgörenlerin nepotizm algılarından daha yüksek düzeyde olduğu tespit edilmiştir.

Tablo 7'de, işgörenlerin nepotizm algılarının işletmedeki çalışma sürelerine göre karşılaştırılması ve iki değişken arasında anlamlı bir farklılık olup olmadığını test etmek amacıyla yapılan tek yönlü varyans (One Way Anova) analizinin sonuçları ayrıntılı olarak yer almaktadır. Yapılan tek yönlü varyans analizinin sonuçlarına göre, katılımcıların nepotizm algıları $(\mathrm{F}=0,312 ; \mathrm{p}=0,870)$, çalışma süreleri açısından değerlendirildiğinde, iki değişkenin grup ortalamaları arasında 0,05 anlamlılık düzeyinde anlamlı bir farklılık olmadığı tespit edilmiştir. Bununla birlikte aritmetik ortalama değerlerinden de anlaşılacağı üzere, Tablo 7'deki değerler dikkate alındığında, çalışma süreleri 12 yıl ve üzerinde olan katılımcı grubunun nepotizm algıları $(\overline{\mathrm{x}}=2,90)$ diğer gruplardan daha yüksek olduğu anlaşılmaktadır.

Tablo 7: Katılımcıların Nepotizm Algılarının Çalışma Süresine Göre Karşılaştırılması

\begin{tabular}{|c|l|c|c|c|c|}
\hline \multirow{2}{*}{ Ölçek } & $\begin{array}{c}\text { İscletmede } \\
\text { Çalışma } \\
\text { Süresi }\end{array}$ & $\bar{X}$ & SS & F & p \\
\hline \multirow{4}{*}{ Nepotizm } & $0-2$ yıl & 2,77 & 1,03 & & \\
\cline { 2 - 4 } & $3-5$ yıl & 2,77 & 1,03 & \multirow{2}{*}{0,312} & \multirow{2}{*}{0,870} \\
\cline { 2 - 4 } & $6-8$ yıl & 2,74 & 1,04 & & \\
\cline { 2 - 4 } & $9-11$ yıl & 2,88 & 1,05 & & \\
\cline { 2 - 4 } & 12 ve üzeri & 2,90 & 1,07 & & \\
\hline
\end{tabular}


Diğer çalışma süresi grupları incelendiğinde, 12 yıl ve üzeri çalışma süresine sahip olan işgörenleri sırasıyla, 9-11 yıl arası çalışan işgörenler $(\bar{x}=2,88), 0-2$ yıl arası çalışan işgörenler $(\bar{x}=2,77), 3-5$ yıl arası çalışan işgörenler $(\bar{x}=2,77)$ ve 6-8 yıl arası çalışan işgörenler $(\bar{x}=2,74)$ takip etmektedir. Varyans analizinden elde edilen bu sonuçlara göre, işgörenlerin deneyim süreleri açısından nepotizm algılarındaki grup ortalamaları birbirine yakın olmakla birlikte, daha uzun süre deneyime sahip olan işgörenlerin daha fazla nepotizm algısına sahip olduğu yorumu yapilabilir.

\section{SONUÇ, TARTIŞMA VE ÖNERILER}

Araştırma kapsamında yedi adet beş yıldızlı otel işletmesinde çalışan 170'i kadın ve 247'si erkek olmak üzere toplamda 417 işgören üzerinde anket tekniği uygulanarak veri toplanmıştır. Toplanan verilerin analizi sonucunda, otel işletmelerinde çalışan işgörenlerin genel nepotizm algıSı orta değere yakın bir değerde $(\overline{\mathrm{x}}=2,80)$ bulunmuştur. Söz konusu bu değerlerin, otel işletmelerinde yöneticiler tarafından ilgili konuların üzerinde önemle durulması gerektiğini göstermektedir. Nepotizm ölçeğine verilen yanıtların analizine göre, işgörenlerin en fazla $(\bar{x}=3,34)$ katılım gösterdiği konu; çalıştıkları işletmeye eleman alımlarında yönetim kadrosunda yer alan kişilerin referans olmasının oldukça önemli olduğudur. Çok çalışsalar ve başarılı olsalar bile, yöneticilerinin tanıdıkları olan işgörenlerin önüne geçemeyeceklerini kabullenmiş olan işgörenlerin grup ortalamaları da $(\overline{\mathrm{x}}=2,89)$ göz ardı edilemeyecek niteliktedir. Bu kabullenme şekli, zamanla işgörenlerin örgüte olan bağlllı̆̆ını, tatmin düzeyini, örgüt içindeki güven düzeylerini ve doğal olarak dolaylı veya doğrudan performanslarının düşmesine sebebiyet verebilecektir. İşgörenlerin alt ve orta kademedeki yöneticilerinin tanıdıkları olan diğer işgörenlere daha 1 llımlı davrandığı algıSı da katılımcıların yüksek düzeyde $(\bar{x}=2,88)$ nepotizm algısına sahip olduğu bir diğer konudur. Ulaşılan bu sonuç ile Arslaner vd., (2014)'nin nepotizm uygulamalarında yeteneksiz kişilerin istihdam edilmesi, tanıdıklara daha farklı yaklaşılması, haksız terfi sistemi gibi uygulamaların işgörenler üzerinde olumsuz etki yaparak, adalet algı düzeylerinin azalabileceğini belirtmesi paralellik göstermektedir. Nepotizm ölçeğinde yer alan ifadelere verilen yanıtların aritmetik ortalamalarına göre, işgörenlerin en düşük düzeyde hesaplanan $(\bar{x}=2,25)$ nepotizm algısı ise işletme içinde yöneticilerin tanıdığı olan işgörenlerden çekinmedikleri konusudur. Nepotizm uygulamaları işgörenler arasında olumsuz etkiler yaratarak, ciddi boyutlarda motivasyon eksikliği, yabancılaşma ve örgütsel bağlılığın azalması (Günel, 2005; Develi, 2008; Büte, 2011a; Karahan ve Yllmaz, 2014; Pelit vd., 2015), düşük adalet algısı (Karacaoğlu ve Yörük, 2012; Arslaner vd., 2014), düşük iş tatmini, iş stresinin artması ve işten ayrılma niyetinin artması (Araslı ve Tumer, 2008; Asunakutlu ve Avcı, 2010; Büte, 2011b) gibi olumsuz örgütsel sonuçlar doğurabilmektedir. Bu bakımdan bu konuda işletme yöneticileri tüm faaliyetlerindeki uygulamalarında bu hususu göz önüne alarak, zaman zaman çalışanlarının bu algılarını kontrol etmeleri ve sorun varsa bunlara neden olan hususların ortadan kaldırılmasına yönelik tedbirlerin alınması noktasında çaba göstermelidirler.

Araştırma kapsamında incelenen işgörenlerin nepotizm algılarının sahip oldukları bireysel/demografik özellikleri açısından $t$-testi ve varyans analizi kullanılarak karşılaştırılmıştır. Bu doğrultuda işgörenlerin nepotizm algıları, cinsiyetleri, yaşları, çalıştıkları bölümleri ve çalışma süreleri açısından karşılaştırıldığında grup ortalamaları arasında anlamlı bir farklılık olmadığı sonucuna ulaşılmıştır $(p>0,05)$. Diğer taraftan, işgörenlerin medeni durumlarına göre nepotizm algılarının 0,05 anlamlılık düzeyinde istatistiki açıdan anlamlı bir farklılık gösterdiği tespit edilmiştir $(p<0,05)$. Karacaoğlu ve Yörük (2012)'ün nepotizm ve örgütsel adalet uygulamalarıyla ilgili yaptıkları araştırmaya göre, aile işletmelerinde çalışan 129 
mavi yakalı işgörenin hem nepotizm hem örgütsel adalet algılamaları bireysel özellikleri açısından herhangi bir farklılık göstermemiştir.

Türkiye'de veya uluslararası literatürde konuyla ilgili olarak gerek turizm sektöründe, gerekse farklı sektörlerde yapılan diğer araştırmaların sonuçları ile bu araştırmanın sonuçları arasında benzerlik olduğu görülmektedir. Araslı vd., (2006)'nin Kuzey Kıbrıs'ta faaliyet gösteren 3, 4 ve 5 yıldızlı otel işletmelerinde nepotizmin insan kaynakları yönetimi üzerindeki etkilerini araştırdığı çalışmada, nepotizmin insan kaynakları yönetimi, iş tatmini, işten ayrılma niyeti ve ağızdan ağıza olumsuz tanıtım üzerinde önemli derecede olumsuz etkilerinin olduğu tespit edilmiştir. Araslı ve Tumer (2008)'in banka sektöründe gerçekleştirdiği ve farklı kayırmacılık kavramları olan nepotizm, favoritzm (kayırma, iltimas(çılık)) ve kronizm (eş-dost kayırma)'in iş stresi ile iş tatmini üzerindeki ilişkisini incelediği araştırmada, söz konusu kavramların üçünün de etkili olduğu, ancak en fazla nepotizmin olumsuz yönde etkilediği sonucuna ulaşılmıştır. Asunakutlu ve Avcı (2008)'nın Muğla İlinde mermercilik sektöründe faaliyet gösteren beş aile işletmesinde nepotizm ve iş tatmini arasındaki ilişkiyi araştırdıkları çalışmanın sonucunda, özellikle terfi ve işlem kayırmacılığının işgörenlerin iş tatmin düzeyleri üzerinde olumsuz etkileri olduğu, ancak işe alım sürecinde nepotizm algısının iş tatmin düzeylerini etkilemediği ortaya çıkmıştır. Büte (2011a)'nin kamu bankalarında kayırmacılığın çalışanlar üzerindeki etkilerini incelediği araştırmanın sonucuna göre, kayırmacılık arttıkça çalışanların iş stresi de artmakta, iş tatmini, işverene güveni ve motivasyonu ise azalmaktadır. Yine Büte (2011b)'nin Trabzon İlinde faaliyet gösteren aile şirketlerinde çalışan ve bu aileye mensup olmayan 130 işgören üzerinde gerçekleştirdiği araştırmada, nepotizm algısının işgörenlerin iş tatminini negatif yönde; iş stresi, olumsuz söz söyleme ve işten ayrılma niyetlerini ise pozitif yönde etkilediği tespit edilmiştir. Keleş vd., (2011) tarafından kayırmacılık ve örgütsel güven ilişkisini ortaya koymak amacıyla, İstanbul'da faaliyet gösteren dokuz tekstil firmasında çalışan 240 işgören üzerinde gerçekleştirilen çalışmanın sonucunda da nepotizmin örgütsel güven üzerinde negatif etkisinin olduğu ortaya konulmuştur. Erdem vd., (2013)'nin Kütahya'da faaliyet gösteren aile işletmesi niteliğindeki dört otel işletmesinde çalışan 99 işgören üzerinde gerçekleştirdiği çalışmada, nepotizm algısının örgütsel bağlılık üzerinde olumsuz etkileri olduğu sonucuna ulaşılmıştır. Afyon Kocatepe Üniversitesi Hastanesinde farklı unvanlara sahip 272 sağlık çalışanı üzerinde Karahan ve Yılmaz (2014) tarafından yapılan araştırmanın sonucunda ise nepotizmin çalışanların örgütsel bağlılığını olumsuz yönde etkilediği görülmüştür. Muğla'nın farklı ilçelerinde faaliyet gösteren 3, 4 ve 5 yıldızlı toplamda yirmi adet otel işletmesinde çalışan 405 işgörenin kayırmacılık algısı ile iş tatmini arasında negatif yönde ve anlamlı ilişki bulunurken; kayırmacılık algısı ile işten ayrılma niyeti arasında pozitif yönde ve anlamlı ilişki olduğu gözlenmiştir (Erdem ve Karataş, 2015). Pelit vd., (2015)'nin konuyla ilgili olarak Antalya ve İstanbul illerindeki 5 yıldızlı otel işletmelerinde gerçekleştirdiği çalışmada, nepotizm ile örgütsel sessizlik ve örgütsel yabancılaşma arasında pozitif yönde anlamlı ilişkiler olduğu; nepotizm ile örgütsel bağlllık arasında ise negatif yönde anlamlı ilişkiler olduğu tespit edilmiştir. Araslı vd., (2016)'nin K.K.T.C.'nde bulundan 3 ve 4 yıldızlı otellerde toplam 299 çalışan ile gerçekleştirdiği çalışmanın sonucunda ise, nepotizmin prosedürel adalet ve iş tatminini negatif ve anlamlı bir şekilde etkilediği tespit edilmiştir. Bu kapsamda söz konusu bu araştırmada da gerek doğrudan gerekse dolaylı olarak konuyla ilgili olarak gerçekleştirilen başka araştırma sonuçlarıyla paralellikler gözlenmiş olup, araştırmadan elde edilen sonuçlara göre, işgören algısında nepotizm hakkında genel olarak turizm sektörü, otel işletmeleri ve otel işletmelerinde çalışan yöneticiler için bazı öneriler geliştirilmiştir. Söz konusu bu öneriler aşă̆ıdaki gibi sıralanabilir: 
- Turizm sektöründe faaliyet gösteren bütün işletmelerde personel alımı liyakat sistemine göre yapılarak, akraba ve arkadaşlık ilişkileri işgören yeteneği ve becerisinin önüne geçmemeli ve alım süreci her potansiyel işgören için aynı işlemelidir.

- Her sektörde olduğu gibi, turizm sektöründe de işgörenler yüksek düzeyde tatmin sağladığ1 ve güven duyduğu örgütlerde daha verimli olduğu için, turizm sektöründe buna uygun örgüt ortamının oluşturulması için çaba harcanmalıdır.

- Fazla sayıda personel istihdam edildiği bilinen otel işletmelerinde, yetki devri öncelikle tanıdıklara verilmesinde ziyade, işi hakkıyla yapabilen işgörenlere devredilmesi yerinde olacaktır.

- Otel işletmelerinde uygulanan terfi ve yükselme olanakları sadece tanıdıklara değil, terfi etmeyi ve yükselmeyi hak eden bütün işgörenlere sağlanmalıdır.

- Otel işletmelerinde işgörenlere tanınan olanaklar kişi ayrımı yapılmadan her işgörenin (yetki dahilinde) kullanımına açık tutulmalıdır.

- Yöneticilerin eş, dost, akraba, tanıdık kayırmadan bütün çalışanlara eşit ve adil davranması ve bütün ödül/ceza sisteminin her çalışan için eşit şekilde uygulanması gerekmektedir.

Bu konuda, gelecek dönemlerde yapılacak olan çalışmalar için ise şunlar önerilebilir;

- Nepotizm ile iş stresi, iş tatmini, örgütsel bağlllık, genel örgütsel güven, sinizm, örgütsel çatışma, işe devamsızlık, örgütsel yabancılaşma, işten ayrılma niyeti ve işgören devri gibi örgütsel değişkenler arasındaki ilişki ve etkinin farklı sektörlerde araştırılmış olmasına rastlanıldığına rağmen, turizm sektöründe bu konuda fazla çalışmaya rastlanamamıştır. Dolayısıyla bu türden örgütsel davranışlar ile nepotizm arasındaki ilişki/etki turizm sektöründe faaliyet gösteren işletmeler açısından da incelenebilir.

Gerek araştırma konusu ile ilgili daha önce, gerekse Afyonkarahisar özelinde gerçekleştirilen bu araştırma sonuçlarına yansıdığı üzere, nepotizm algısı işgörenler açısından oldukça olumsuz sonuçları beraberinde getirerek örgüte de yansımaları olumsuz olmaktadır. Bu çerçevede, özellikle bu algının ortadan kaldırılmasına yönelik ilgili işletme yöneticilerine büyük görevler düşmektedir. Bu doğrultuda, gerek işgörenler gerekse işletmeler açısından olumsuz bir alg1 olan çalışanların nepotizm algılarının ortadan kaldırılmasına yönelik otel işletmeleri yöneticilerinin; yukarıda bahsedilen önerileri kendi uygulamalarına yansıtmaları, gerek kendilerinin yöneticilik becerilerinin geliştirilmesi, gerekse işgörenlerden daha fazla katkı alınması ve bunun da işletmenin uzun dönemli amaçlarına ulaşmasında katkı sağlayacak hususlardan olacaktır.

\section{KAYNAKÇA}

Abdalla, H. F. Maghrabi, A. S. and Al-Dabbagh, T. H. (1994). Research Note: Assessing the Effect of Nepotism on Human Resource Managers. International Journal of Manpower. 15(1):60-67.

Abdalla, H. F. Maghrabi, A. S. and Raggad, B. G. (1998). Assessing the Perceptions of Human Resource Managers Toward Nepotism a Cross-Cultural Study. International Journal of Manpower. 19(8):554-570.

Aközer, M. (2003). Kamuoyu Gözüyle Kamuda Yolsuzluk. Görüş Dergisi, Aralık. 14-23. 
Araslı, H., Bavik, A. and Ekiz, E. H. (2006). The Effects of Nepotism on Human Resource Management: The Case of Three, Four and Five Star Hotels in Northern Cyprus. International Journal of Sociology and Social Policy, 26(7/8): 295-308.

Arasli, H. and Tumer, M. (2008). Nepotism, Favoritism and Cronyism: A Study of Their Effects on Job Stress and Job Satisfaction in the Banking Industry of North Cyprus. Social Behavior and Personality, 36(9):1237-1250.

Araslı, H. Arıcı H. H. ve Araslı, F. (2016). Nepotizmin İş Tatmini Üzerinde Etkisinde Prosedürel Adaletin Aracı Rolü: K.K.T.C. Otelcilik Sektörü Üzerine Bir Araştırma. Ekonomi ve Yönetim Araştırmaları Dergisi. 5(2):2-20.

Arslaner, E., Erol, G. ve Boylu, Y. (2014). Konaklama İşletmelerinde Nepotizm ve Örgütsel Adalet Algısı Üzerine Bir Araştırma. Muğla Sıtkı Koçman Üniversitesi Sosyal Bilimler Enstitüsü Dergisi, 32(1):62-77.

Asunakutlu, T. ve Avcı, U. (2009). “Nepotizm-İş Tatmini İlişkisi: Aile İşletmelerinde Bir İnceleme", 17.Ulusal Yönetim ve Organizasyon Kongresi Bildiriler Kitabı, 730-736.

Asunakutlu, T. ve Avcı, U. (2010). Aile İşletmelerinde Nepotizm Algısı ve İş Tatmini İlişkisi Üzerine Bir Araştırma. Süleyman Demirel Üniversitesi İktisadi ve İdari Bilimler Fakültesi Dergisi, 15(2):93-109.

Bayhan, V. (2002). Demokrasi ve Sivil Toplum Örgütlerinin Engelleri: Patronaj ve Nepotizm. Cumhuriyet Üniversitesi İ̈BF Dergisi. 26(1):1-13.

Below, A. (2003). In Praise of Nepotism: A Natural History. New York: Doubleday.

Büte, M. (2011a). Kayırmacılığın Çalışanlar Üzerine Etkileri İle İnsan Kaynakları Uygulamaları İlişkisi: Türk Kamu Bankalarına Yönelik Bir Araştırma. Atatürk Üniversitesi Sosyal Bilimler Enstitüsü Dergisi, 15(1):383-404.

Büte, M. (2011b). Nepotizmin İş Stresi, İş Tatmini, Olumsuz Söz Söyleme ve İşten Ayrılma Niyeti Üzerine Etkileri: Aile İşletmeleri Üzerinde Bir Araştırma. Çukurova Üniversitesi Sosyal Bilimler Enstitüsü Dergisi, 20(1):177-194.

Büte, M. ve Tekarslan, E. (2010). Nepotizmin Çalışanlar Üzerine Etkileri: Aile İşletmelerine Yönelik Bir Saha Araştırması. Ekonomik ve Sosyal Araştırmalar Dergisi. 6(1):1-21.

Ciulla, J. B. (2005). In Praise of Nepotism? Business Ethics Quarterly. 15(1):153-160.

Develi, N. (2008). Aile İşletmeleri, Aile İşletmelerinde Karşılaşılan Yönetim ve Organizasyon Sorunları: Mersin Örneği. (Yayınlanmamış Yüksek Lisans Tezi). Pamukkale Üniversitesi Sosyal Bilimler Enstitüsü, İşletme Anabilim Dalı, Denizli.

Erdem, B. Çeribaş, S. ve Karataş, A. (2013). Otel İşletmelerinde Çalışan İşgörenlerin Kronizm(Eş-Dost Kayırmacılığı) Algıları: İstanbul'da Faaliyet Gösteren Bir, İki ve Üç Yıldızlı Otel İşletmelerinde Bir Araştırma. Çukurova Üniversitesi İ̈BF Dergisi. 17(1):51-69. 
Erdem, B. ve Karataş, A. (2015). The Effects of Cronyism on Job Satisfaction and Intention to Quit the Job in Hotel Enterprises: The Case of Three, Four and Five Star Hotels in Muğla, Turkey. Manas Sosyal Araştırmalar Dergisi, 4(1):55-74.

Erdem, B., Ceylan, U. ve Saylan, U. (2013). Aile İşletmelerinde Nepotizm ve Örgütsel Bağlllık İlişkisi: Kütahya'da Faaliyet Gösteren Otel İşletmelerinde Bir Araştırma. Uludağ Üniversitesi İktisadi ve İdari Bilimler Fakültesi Dergisi, 32(2):171-197.

Ford, R. and McLaughin, F. (1985). Nepotism. Personnel Journal. 64(9):57-61.

Fukuyama, F. (1998). Güven, Sosyal Erdemler ve Refahın Yaratılması. (Çev: A. Buğdaycı), Türkiye İş Bankası Yay., Ankara.

Günel, R. (2005). Aile İşletmelerinde Yönetimin Bir Sonraki Kuşağa Devrinde Karşılaşılan Sorunların Tespitine ve Bu Sorunların Çözümüne İlişkin Bir Araştırma. (Yayınlanmamış Yüksek Lisans Tezi). Çukurova Üniversitesi Sosyal Bilimler Enstitüsü, İşletme Anabilim Dalı, Adana.

Hofstede, G. (1998). Identifying Organizational Subcultures: An Empirical Approach. Journal of Management Studies. 35(1):1-12.

Hutcheson, O.J. (2002). Negotiating Nepotism. Financial Planning. February. 75-76.

Ichniowski, T. (1988). The New Nepotism: Why Dynasties Are Making a Comeback. Business Week. 31. 106-109.

Karacaoğlu, K. ve Yörük, D. (2012). Çalışanların Nepotizm ve Örgütsel Adalet Algılamaları: Orta Anadolu Bölgesinde Bir Aile İşletmesi Uygulaması. "İ̧̧-Güç" Endüstri İlişkileri ve İnsan Kaynakları Dergisi, 14(3):43-64.

Karahan, A. ve Yılmaz, H. (2014). Nepotizm ve Örgütsel Bağlılık Arasındaki İlişkinin İncelenmesi ve Bir Uygulama. Selçuk Üniversitesi İktisadi ve İdari Bilimler Fakültesi Sosyal ve Ekonomik Araştırmalar Dergisi (The Journal of Social and Economic Research), 14(27):123-148.

Keleş, H. N. Özkan, T. K. and Bezirci, M. (2011). A Study on the Effects of Nepotism, Favoritism and Cronyism on Organizational Trust in the Auditing Process in Family Businesses in Turkey. International Business \& Economics Research Journal. 10(9):9-16.

Kiechel, W. (1984). How to Relate to Nepotism. Fortune. February. 143-144.

Masters, R. D. (1983). The Biological Nature of the State. World Politics. 35(2):161-193.

Özdamar, K. (2001). Paket Programlar ve İstatistiksel Veri Analizi (Çok Değişkenli Analizler. (4. Baskı). Eskişehir: Kaan Yayınları.

Özler, H. Özler, D.E. ve Gümüştekin, G.E. (2007). Aile İşletmelerinde Nepotizmin Gelişim Evreleri ve Kurumsallaşma. Selçuk Üniversitesi Sosyal Bilimler Enstitüsü Dergisi. 1(17):437-450. 
Özsemerci, K. Tarhan, R.B. Gençkaya, Ö.F. Ergül, E. ve Özbaran, H. (2002). Türk Kamu Yönetiminde Yolsuzluklar, Nedenleri, Zararları ve Çözüm Önerileri. Yüksek Lisans Tezi, TODAİE, Ankara.

Pelit, E., İstanbullu Dinçer, F. ve Kılıç, İ. (2015). The Effect of Nepotism on Organizational Silence, Alienation and Commitment: A Study on Hotel Employees in Turkey. Journal of Management Research, 7(4):82-110.

Sargut, S. (2010). Kültürler Arası Farklılaşma ve Yönetim. İmge Kitabevi. Ankara.

Seçilmiş, C. and Uysal D. (2016). The Moderating Role of Nepotism in the Effect of Employee Empowerment on Perceptions Regarding Organizational Justice at Hospitality Organizations. International Journal of Business and Management Invention. 5(9):65-76.

Sekaran, U. (2003). Research Methods for Business. New York: John Wiley. 